\title{
The International Law Principle of Permanent Sovereignty over Natural Resources as an Instrument for Development: The Case of Zimbabwean Diamonds
}

\author{
Yolanda T. Chekera and Vincent O. Nmehielle* \\ School of Law, University of the Witwatersrand, Johannesburg, South Africa
}

\begin{abstract}
Extensive research has shown that revenue from the exploitation of natural resources can sustain development. Conversely, development research literature has shown that many developing countries have failed to use the natural resources to improve and sustain good living for their citizens. In most cases, those in political offices have squandered the resources and benefits that have accrued from the country's natural endowments. This article explores how the international law principle of permanent sovereignty over natural resources (PSNR) could be used as a vehicle for development, particularly looking at the case of Zimbabwean diamonds. While the principle could be an instrument for development, this article argues that legislation governing mining in Zimbabwe is not facilitative of a people-centred interpretation of the principle. Mining legislation vests the custodial right over the country's mineral resources in the President. This creates an opportunity for abuse, as it limits the extent to which the people, as beneficiaries of the principle, can lay claim to the content of the principle. It also effectively limits any say the people may have on how revenue from the sale of diamonds is utilised, and how they would want to benefit from the resource. The article concludes that there is a need for legislative reform that speaks to development that is people-centred without which the majority of the people will keep sinking into the doldrums of extreme poverty, despite the country's resource endowment. The hope is that the new Zimbabwean constitution will provide the impetus in this regard.
\end{abstract}

Keywords

Permanent sovereignty; natural resources; right to development; people-centered development; mining legislation; Zimbabwean diamonds

\section{Introduction}

The country is starving, civil servants are going on strike, hospitals have no medicine, agriculture have (sic) no chemicals and schools have no books. We cannot continue to be playing around like you guys are doing... Are our diamonds meant to benefit certain individuals or it is intended to

\footnotetext{
*) Corresponding author, e-mail: Vincent.Nmehielle@wits.ac.za. Yolanda T. Chekera is LLB (Wits), LLM (Wits). Vincent O. Nmehielle is a Professor of Law and the Head of the Wits Programme on Law, Justice \& Development in Africa, School of Law, University of the Witwatersrand, Johannesburg, South Africa. This article is based on a research report submitted to the University of the Witwatersrand School of Law for the Master of Laws (LLM) Degree.
} 
benefit the nation? - Edward Chindori-Chininga, Chair, Mines and Energy Committee to a government witness. ${ }^{1}$

The quotation above speaks to what Duruigbo describes as a 'pressing and perplexing problem throughout the world today'; that is, 'the inability of many countries to convert valuable natural resources into an enhanced standard of living for their citizens.' ${ }^{2}$ This problem is identified by Gleb et al. who studied the experiences of six developing oil exporters, namely, Algeria, Ecuador, Indonesia, Nigeria, Trinidad and Tobago, and Venezuela from the 196os to the 1980 s and concluded that despite the massive oil revenues generated by these countries, they performed lower than other developing non-oil exporters in terms of growth and development. ${ }^{3}$ In addition, the titles of several studies are revealing: 'How Oil Revenues Can Destroy a Country'; 'The Years that the Locust Hath Eaten: Oil Policy and OPEC Development Prospects'; 5 and 'Oil Wealth: A Very Mixed Blessing.' In the latter study, Amuzegar quotes Ali A. Attiga who argues that oil-exporting countries "have gained the least, or lost the most, from the discovery and development of their resources. ${ }^{7}$ As such, there is robust empirical evidence to support the inverse relationship between natural resource endowment and an enhanced standard of living - a phenomenon referred to as the 'resource curse.'8

Scholars like Gelb ${ }^{9}$ who coined the expression 'resource curse' and many others have analysed the phenomenon and attempted to explain it. ${ }^{10}$ Some of the explanations for the phenomenon include long-run declines in product prices, exchange rate inflation and government complacency linked to the 'easy rents' generated by natural resource booms. ${ }^{11}$ Although some scholars refer to the phenomenon as the 'resource curse', Duruigbo describes it as the 'leadership curse', a phenomenon whereby those in political offices ensure that the rest of the population receives almost no benefit from the resources with which their countries have been abundantly endowed. ${ }^{12}$ While various scholars have tried to explain the phenomenon,

\footnotetext{
1) Partnership Africa Canada, 'Diamonds and clubs: the militarized control of diamonds and power in Zimbabwe', available online at http://pacweb.org (last accessed 15 July 2011).

2) E. Duruigbo, 'Permanent sovereignty over natural resources and people's ownership of natural resources in international law', 38 George Washington International Law Review (2006), 33-100.

3) A.H. Gelb and associates, Oil windfalls: blessing or curse? (Oxford University Press, Oxford, 1988), at pp. 134-136.

4) Ibid., at 8.

5) W. Levy, 'The years that the locust hath eaten: oil policy and OPEC development prospects', 57 Foreign Affairs (1978), 287-305.

6) Amuzegar 'Oil wealth: a very mixed blessing', 6o Foreign Affairs (1982), 814-835.

7) Ibid., at 815 .

8) K. Hamilton and G. Ruta, 'From curse to blessing: natural resources and institutional quality', Environment Matters (2006), 24-27. See Duruigbo, note 2 above, at pp. 33-34.

9) Gelb et al., note 3 above.

10) Hamilton and Ruta, note 8 above, at p. 24.

11) Ibid.

12) Duruigbo, note 2 above, at pp. $33^{-34}$.
} 
there is no comprehensive theory to explain it. ${ }^{13}$ However, what is clear at this point is that scholars are looking for an explanation of the phenomenon in the interaction between government behaviour and natural resource wealth. ${ }^{14}$

According to Hamilton and Ruta, 'natural resources are gifts that require proper management to provide sustained growth, ${ }^{15}$ more so in developing counties where their importance in determining national wealth is crucial. ${ }^{16}$ Accordingly, the sum total of the wealth accruing from natural resources in low income countries is very significant and 'is substantially larger than the share of produced capital. ${ }^{17}$ This means that if properly managed, natural resources can yield rents that can be an important source of development finance..$^{18}$ In fact, sound management of natural resources can support and sustain the welfare of poor countries and people in poor countries, as they move up the development ladder. ${ }^{19}$ This is in line with research that has shown the causal nexus between a nation's mineral wealth and its potential to develop the economy and raise the living standard of its citizens. ${ }^{20}$ However, as Hamilton and Ruta point out 'natural resource rents often favour the creation of factional states in which those managing the rents tend to create mechanisms to control economic and political power.' ${ }^{21}$

The potential financial revenue that could be generated from the sale of the 'recently' discovered diamonds in the Chiadzwa area of Marange district, about 100 kilometres southwest of Zimbabwe's eastern city of Mutare, is reported to range from a conservative US $\$ 1.2$ million to US $\$ 200$ million and even US $\$ 1$ billion per month. ${ }^{22}$ If one goes with the latter figure it means that the country will be able to earn at least US $\$ 12$ billion per year - a figure greater than any previous Gross Domestic Product (GDP) figures for Zimbabwe even during good years of the 1980 s and 1990 s. $^{23}$ Given that in 2009, Zimbabwe needed US $\$ 8.5$ billion to kick start its recovery from a decade of economic meltdown of catastrophic proportions, ${ }^{24}$ the revenue from diamond sales could change the face of Zimbabwe's economic, political and social landscape.

\footnotetext{
13) Hamilton and Ruta, note 8 above, at p. 24.

14) Ibid.

15) Ibid.

16) Ibid.

17) Ibid., at p. 26.

18) Ibid., at p. 25 .

19) Ibid., at p. 26.

20) See the global research report published by the International Institute for Environment and Development, 'Breaking new ground: mining, minerals and sustainable development', available online at http:// www.iied.org/pubs/pdfs/9084IIED.pdf (last accessed 21 August 2011).

21) Hamilton and Ruta, note 8 above, at p. 25.

22) A. Makochekanwa 'Chiadzwa diamonds: Zimbabwe's potential economic recovery option' (2010), available online at http://mpra.ub.uni-muenchen.de/22488/ (last accessed 2 August 2011).

23) Ibid.

24) Government of Zimbabwe, 'Short Term Emergency Recovery Programme (STERP): getting Zimbabwe moving again' (2009).
} 
This article explores how permanent sovereignty over natural resources as a principle (hereafter PSNR or permanent sovereignty principle), could be used as a vehicle for development, particularly looking at the case of Zimbabwean diamonds (hereafter Marange diamonds or Chiadzwa diamonds). The aim of the article is to highlight how PSNR can be a basis that informs Zimbabwean mining legislation and policy to be development-oriented. The article is made up of five parts, including this introductory section, which establishes the basis for the inquiry that this piece makes and contends that the Zimbabwean government's key task is to administer the country's wealth for the benefit of its citizens. Part 2 reviews the historical background of the principle of PSNR and highlights the international instruments that capture it. The part further enquires into who the holders of the right to PSNR are. It also examines the meaning of development and discusses how the principle could result in an enhanced standard of living. Part 3 looks at the history of diamond mining in Zimbabwe. It shows that Zimbabwe is a country endowed with vast mineral wealth, the most important of which could probably be the 'recently' discovered diamonds. It also examines legislation governing mining in Zimbabwe with a view to determining how facilitative it is of development. Part 4 focuses on how the principle of permanent sovereignty over natural resources can act as a legal means of ensuring development for the benefit of the people by addressing the deficiencies in the regulation of mining in Zimbabwe. The article concludes, in Part 5, that while the principle could be an instrument for development, the legislation governing mining in Zimbabwe is not facilitative of a people-centred interpretation of the principle, as the mining legislation vests the custodial right over the country's mineral resources in the President. It makes the point that this creates an opportunity for abuse, as it limits the extent to which people can claim the content of the principle. As a result, there is need for legislative reform that speaks to development that is people-centred, without which the majority of the people will keep sinking into the doldrums of extreme poverty, despite the country's resource endowment.

\section{The Principle of Permanent Sovereignty over Natural Resources and Development}

\subsection{Meaning of Sovereignty}

The meaning, scope and contours of sovereignty are extensively debated but have not been subjected to a precise definition. 'Traditionally, sovereignty has been identified as having four main characteristics. ${ }^{25}$ First is the power of a state to

25) Jackson 'Sovereignty - modern: a new approach to an outdated concept', 97 American Journal of International Law (2003), 782-802, at p. 786. 
exercise supreme authority over all persons and things within its territory. ${ }^{26}$ This also includes the power to legislate on any issue that is within the state's jurisdiction. Secondly, sovereignty consists of the capability of a state to 'regulate movement across its borders. ${ }^{27}$ Inherent in sovereignty also is the recognition that the territorial integrity of a state is inviolable and as such has independence from interference from other states. ${ }^{28}$ It therefore defines the boundaries that protect one state from the intervention of others. It is generally also considered to be the legal identity of the state in international law, an equality of status with all other states and the claim to be the sole official agent acting in international relations on behalf of a society. ${ }^{29}$ Lastly, the state is 'free to make its foreign policy choices freely. ${ }^{30}$

\subsection{Origin and Evolution of the Principle of PSNR}

One of the earliest references to the principle of permanent sovereignty over natural resources was its introduction by Chile in the United Nations Commission on Human Rights (UNCHR) in 1952. The principle would subsequently develop through numerous resolutions and declarations. ${ }^{31}$ One of the earliest formulations of the principle is found in the United Nations General Assembly Resolution 626 (VII) of 21 December 1952. ${ }^{32}$ The Resolution recognised that countries had a right to determine the use of their natural resources so as to ensure the realisation of their economic development. ${ }^{33}$ In 1958, through UN General Assembly Resolution 1314, the principle would be recognised as a basic element of the right to self determination. Up until that point the principle was only enshrined in resolutions concerned with private investment. ${ }^{34}$ This, however, changed after $195^{8}$ when the principle became intertwined with issues of human rights and self determination. ${ }^{35}$

This period coincided with decolonisation when developing countries also began to assert their right over their natural resources as means of generating internal revenue. The newly independent states were convinced that their independence would only be complete and effective when they had attained political

\footnotetext{
26) Ibid.

27) Ibid.

28) Ibid.

29) Ibid.

30) Ibid.

31) F. Visser, 'The principle of permanent sovereignty over natural resources and the nationalisation of foreign interests', 21 CILSA (1988), 76-91.

32) J.N. Hyde, 'Permanent sovereignty over natural wealth and resources', 50 American Journal of International Law (1956), 854-867, at p. 855 .

33) Ibid.

34) Ibid.

35) L.S. Clark, 'International law and natural resources', 4 Syracuse Journal of International Law and Commerce (1976), 377-390 at 378.
} 
self-determination as well as effective control over their natural resources. This was against the backdrop that, prior to decolonisation, private corporations from the industrialised world undertook investments in colonised countries under very favourable conditions and a significant portion of the proceeds of those investments found their way back to their home countries. ${ }^{36}$ As control over mining industries in developing countries was particularly of great concern to the underdeveloped countries, the developing countries were quite taken by this principle as they saw it as a means through which they would gain control over their natural resources and, consequently, pushed for its promotion in the UN General Assembly. ${ }^{37}$

The $195^{2}$ Resolution stressed the importance of promoting economic development to achieve universal peace and that to achieve economic development it was important that countries have the right to freely use and exploit their natural resources. ${ }^{38}$ Following the $195^{2}$ Resolution, discussion of the concept took place in several fora such as the ninth session of the UN General Assembly Debates in 1954. In 1955, permanent sovereignty over natural resources was discussed in the Human Rights Commission, the Third Committee of the UN General Assembly and the Economic and Social Council of the United Nations (ECOSOC). Six years after the first resolution, the UN General Assembly recognised the right to permanent sovereignty over natural resources as a basic element of the right to self-determination through the adoption of Resolution 1314 (XIII) on 12 December 1958. ${ }^{39}$ The adoption of this Resolution gave birth to the Commission on Permanent Sovereignty over Natural Resources which had the task of determining the nature of the right, the manner in which the right should be exercised and what measures should be taken into account according to international law. ${ }^{40}$

The work of the Commission culminated in the adoption by the UN General Assembly in 1962 of Resolution 1803 (XVII) entitled 'Permanent Sovereignty over Natural Resources.' The Resolution constituted the broadest and most explicit declaration from the United Nations on the subject. ${ }^{41}$ In addition, it was the last resolution dealing with the concept that was supported by a large majority of states from all groups concerned, as it embodied a balance between the interests of capital importing and capital exporting countries. The Resolution as a whole

\footnotetext{
36) N. Kofele-Kale, 'Patrimonicide: the international economic crime of indigenous spoliation', 28 Vanderbilt Journal of Transnational Law (1995), 45-118, at p. 85 .

37) T. Wälde, 'Third world mineral development: recent issues and literature', 2 Journal of Energy and Natural Resources Law (1984), 282-301.

38) Resolution 626 (VII).

39) Visser, note 31 above, at p. 77.

40) Kofele-Kale, note 36 above, at p. 8o; N. Schrijver, Sovereignty over natural resources: balancing rights (Cambridge University Press, Cambridge, 1997), at p. 75 .

41) Ibid., at 82 .
} 
was adopted with eighty seven votes to two, with twelve abstentions. ${ }^{42}$ Like its predecessors, it once again linked the concept to economic independence and self determination. ${ }^{43}$ Resolution 1803 , among other things, stated that permanent sovereignty over natural resources must be exercised in the interest of 'national development and well-being of the people of the State concerned; that exploration, development, disposition of resources, as well as capital imported shall be governed by national legislation; and that any appropriation of property would be compensated in a manner provided for in national legislation. ${ }^{44}$

From the 196os, developing countries actively pursued the implementation of the principle of permanent sovereignty because they perceived this as the mainstay for their economic development and for redistribution of wealth. ${ }^{45}$ After 1962 , the debate on permanent sovereignty over natural resources evolved in various directions, such as the call by developing countries for the establishment of a new economic order. Following the recommendations of the Second Committee that had discussed the matter in October 1966, the UN General Assembly adopted Resolution 2158 on 28 November 1966. The Resolution emphasized the achievement of maximum development of natural resources of developing countries and the means to ensuring that the countries were able to carry on the development of the natural resources themselves ${ }^{46}$ According to Kofele-Kale, this Resolution represented 'a strong statement against concession agreements of the past and affirmed permanent sovereignty as a means of increasing the economic and technological advancement of developing states. ${ }^{.47}$

In December of 1966, two other instruments were also adopted and opened for ratification. These were the International Covenant on Economic, Social and Cultural Rights (ICESCR) and the International Covenant on Civil and Political Rights (ICCPR). Though these two instruments did not directly mention the principle of permanent sovereignty over natural resources, they stated that 'all peoples may for their own ends freely dispose of their natural wealth and resources without any prejudice to any obligations arising out of international economic cooperation. ${ }^{48}$ In the years following, the concept would be emphasized in Resolution 2626 of 1970 and Resolution 3171 of 1973. In December 1974, the UN General Assembly adopted the Charter of Economic Rights and Duties of States (CERDS) which was aimed at establishing and improving the norms of universal application for the development of international economic relations on a just and equitable basis.

\footnotetext{
42) N. Schrijver, Sovereignty over natural resources: balancing rights and duties (Cambridge University Press, Cambridge, 1997), at p. 76 .

43) Kofele-Kale, note 36 above, at p. 82.

44) GA Res 1803 (XVII), UN. Doc A/5217 (Dec 14, 1962).

45) Schrijver, note 42 above, at p. 82.

46) GA Res 2158 (XXI), UN. Doc A/6518 (Nov 28, 1966).

47) Kofele-Kale, note 36 above, at p. 85 .

48) See Article 1 of the International Covenant on Economic, Social and Cultural Rights. See also Article 2 of the International Covenant on Civil and Political Rights.
} 
Among the fifteen principles listed in the Charter, Article 2 recognises and enunciates the principle of permanent sovereignty over natural resources. Again, in 1974, the principle was included in the Declaration on the Establishment of a New International Economic Order (NIEO) and the Programme of Action on the Establishment of a New International Economic Order. As Schrijver points out, unlike the resolutions of the 1960 s on permanent sovereignty over natural resources, the NIEO resolutions were adopted in an atmosphere of confrontation which resulted in them being adopted with lower votes. ${ }^{49}$

Outside the UN General Assembly Resolutions and UN based multi-lateral treaties, the principle of permanent sovereignty also found its way into other instruments. The African Charter on Human and Peoples' Rights (African Charter), although it does not use the phrase 'permanent sovereignty over natural resources', seemed to recognise the central element of the principle in Article 21; that is, the right of 'all peoples' to 'freely dispose of their wealth and natural resources. ${ }^{50}$ The 1992 Rio Declaration on Environment and Development, in Article 2, also recognised the sovereignty of a state to exploit their natural resources 'pursuant to their own environmental and developmental policies.' It places emphasis on the connection of the principle with its original aim of development. ${ }^{51}$ The principle of permanent sovereignty over natural resources thus gained widespread international recognition, allowing it to become an important part of international law on the utilisation of domestic natural resources.

\subsection{Beneficiaries of the Principle}

With the near completion of the decolonisation process during the 196os, resolutions on permanent sovereignty over natural resources increasingly referred to developing countries or only to states as subjects of the right. ${ }^{52}$ As discussed above, this, it may be observed, was against the background that, hitherto, under colonisation, these were resources that had largely been expropriated by international corporations for the benefit of their colonial home countries. The resolutions were, however, not always consistent. A perusal of the resolutions reveals a glaring inconsistency on whom the right to permanent sovereignty over natural resources vests. ${ }^{53}$ Resolutions 1320 and 1803 recognise the right as belonging to peoples and nations, while others affirm it as a right belonging to states. As a result, there have been different interpretations regarding the rightful bearers of

\footnotetext{
49) Schrijver, note 42 above, at p. 83 .

50) R. Gittleman, 'The African charter on human and peoples' rights: a legal analysis', 22 Virginia Journal of International Law (1981), 667-714, at p. 682, citing Article 21 of the African Charter on Humana and Peoples' Rights.

51) J.A. Hofbauer, The principle of permanent sovereignty over natural resources and its modern implications (LLM thesis, University of Iceland, Reykjavik, 2009), at p. 7 .

52) Schrijver, note 42 above, at p. 23.

53) Duruigbo, note 2 above, at p. 43 .
} 
the right of permanent sovereignty over natural resources. The right has variously been viewed as either belonging solely to the state, or jointly to the state and peoples, or solely to peoples. ${ }^{54}$ Indeed, according to Schrijver, questions on who the subjects entitled to permanent sovereignty are cannot be disassociated from the general discussions on the subjects of international law. ${ }^{55}$

The first view proposes that the right vests solely in the state - that only states are the holders of the right to permanent sovereignty. This view is supported by some of the resolutions on permanent sovereignty such as the CERDS, which only mentions states as the sole custodians of the right to permanent sovereignty. This interpretation, it might be observed, is consistent with the classical conception of international law where only states are considered as subjects of the law, and as such are the only actors that can bear rights. This interpretation, it is argued, emanated from the relations between multinational corporations involved in resource extraction and their host states. ${ }^{56}$ Vesting natural resources in the state, it can be argued, was seen as a means of wresting control of natural resources from the grip of the multinational corporations. As a result, the right of states to legislate for public good in relation to natural resources has become the most common interpretation. ${ }^{57}$ Thus, according to Schrijver, 'the etatist orientation can well be understood as part of the economic and political emancipation process of developing countries. ${ }^{58}$ Other scholars, however, find this approach problematic. According to Duruigbo, 'reading this right as vested in the state could convey the impression that states hold it exclusively and that only the government, as representative of the state, can exercise it, meaning that people would be hamstrung in challenging natural resource policies that are contrary to their interests. ${ }^{59}$ Related to this is the problem endemic in most African countries where the benefits have tended to accrue to those connected to or in government at the expense of the citizens.

The second interpretation, which in some way addresses the above criticism, is that permanent sovereignty over natural resources accrues jointly to the state and to peoples. ${ }^{60}$ This view is supported by the language of some of the relevant instruments dealing with the principle, such as UN General Assembly Resolution 1803. This approach, however, has its own fair share of problems in relation to its interpretation. One of the problems has been the conflation of the two personas, the state and peoples, on the basis that, on the international arena, people act through states. Thus, the state acts as an intermediary in dealing with external interests on behalf of the people in a way that is essentially impossible for the

\footnotetext{
54) Ibid.

55) Schrijver, note 42 above, at p. 24.

56) Kofele-Kale, note 36 above, at p. 92.

57) Ibid.

58) Schrijver, note 42 above, at p. 371.

59) Duruigbo, note 2 above, at p. 44.

60) Ibid.
} 
people to do themselves. ${ }^{61}$ This approach practically translates to the first approach discussed above, which advocates the primacy of the state in relation to natural resources. Crawford thus rightfully argues against this view on the basis that if the rights of peoples are the rights of states then there would be no point in referring to the rights as such. ${ }^{62}$ Indeed, distinction between the state and peoples becomes pertinent where the interests of the people differ from those of the state. ${ }^{63}$

In arguing for the separation of the state and peoples as distinct holders of the right to sovereignty over natural resources, Schrijver highlights that the origin of the principle is twofold, namely sovereignty of states and self-determination of peoples. ${ }^{64}$ Sovereignty is one aspect of the principle and does not expunge the protection sought for people. ${ }^{65}$ This approach finds some support in the drafting history of the principle of permanent sovereignty. As explained by Chile when it first proposed the principle, the primary objective was to underscore the rights of peoples to remain masters of their own natural wealth and resources. ${ }^{66}$ Therefore, it may be concluded that the right to permanent sovereignty is a right of peoples. At the very least, it is argued, the right should jointly reside in the state and the peoples, with the state merely acting as the medium through which the peoples could exercise their rights under international law. This international persona would, however, not be necessary for domestic purposes.

Indeed, on a closer look, international law has been moving away from being focused solely on the rights and duties of states. While states are still the primary subjects of international law, they are no longer the only subjects. The circle of subjects entitled to dispose of natural resources has therefore also changed over the years. ${ }^{67}$ Further, new developments in international law have seen the emergence of rights of the individual and rights that can be exercised by people collectively, such as the right to development. These developments lend support to the view that permanent sovereignty over natural resources should belong to people and not to the state.

The third interpretation is that the right of permanent sovereignty over natural resources belongs to peoples. According to Kofele-Kale, a review of the travaux preparatoires on the Covenant of Economic, Social and Cultural Rights and the Covenant of Civil and Political Rights shows that the representatives consistently spoke of rights of peoples over their natural resources, ${ }^{68}$ while according

\footnotetext{
61) R.N. Kiwanuka, 'The meaning of "people" in the African charter on human and people's rights', 2 The American Journal of International Law (1988), 80-101, at 96.

62) J. Crawford, 'The rights of peoples: "peoples" or "governments"?', 9 Bulletin of the Australian Society of Legal Philosophy (1985), 136-147.

63) Kiwanuka, note 61 above, at p. 83 .

64) Schrijver, note 42 above, at p. 368.

65) Duruigbo, note 2 above, at p. 49.

66) Schrijver, note 42 above, at p. 7.

67) Ibid.

68) Kofele-Kale, note 36 above, at p. 93 .
} 
to Crawford, the precedent for treating questions of permanent sovereignty over natural resources as rights of peoples rather than rights of states is an established one, as indicated in Article 1(2) of the both Covenants mentioned above. ${ }^{69}$ Professor Cassese also supports this view, arguing that Article 1(2) 'is not merely an affirmation of the right of every state over its natural resources; it clearly provides that the right over natural wealth belongs to peoples. 70

While other aspects of permanent sovereignty can only be exercised through the state, we take the view that the right of permanent sovereignty over natural resources accrues primarily to peoples. This is precisely for three reasons - firstly, because governments, particularly in Africa, are not necessarily always representative of their constituents - a problem which has resulted in the 'immiseration' of several people. Secondly, as argued above, there is a growing trend in international law to extend the concept and the principle of self-determination to peoples and groups within existing states. ${ }^{71}$ Thirdly, the right of peoples to utilise their natural resources does not always necessarily require that they be legal persons in international law. This only becomes necessary when the peoples wish to assert their rights externally, that is, against the peoples of other states. As argued from the outset, in post colonial Africa, the greatest threat to the full enjoyment of a peoples' natural resources is now largely from within. The greatest threat is now the abuse of authority or power by those connected to or in government. Indeed, it is precisely for this reason that all the relevant instruments on the right left the necessary implementing legislation to member states.

\subsection{Meaning of Peoples}

If one accepts that permanent sovereignty over natural resources accrues to peoples solely or jointly to peoples and the state, the question then arises as to what the term 'peoples' means. Kiwanuka, discussing the meaning of peoples within the context of the African Charter, points out that at least four meanings of the term are possible. ${ }^{72}$ The term could refer to 'people who are still under colonial domination, a portion of the population, the whole population within a territory, or as a synonym of the state. ${ }^{73}$ Under the African Charter, within the context of economic self-determination, the term has two meanings; that is, as a reference to all peoples, including tribal groups residing within a sovereign state, or

\footnotetext{
69) Crawford, note 62 above, at p. 142.

70) A. Cassese, 'The self-determination of "peoples" ', in L. Henkin (ed.), The International Bill of Human Rights: The Covenant on Civil and Political Rights (Columbia University Press, New York, NY, 1981), pp. 92-113, at p. 94 .

71) E.-I. Daes, 'Prevention of discrimination and protection of indigenous peoples: indigenous peoples' permanent sovereignty over natural resources', available online at www.un.org/esa/socdev/unpfii/documents/ E.C.19.2010.9\%20EN.pdf (last accessed 2 September 2011).

72) Kiwanuka, note 61 above, at p. 90.

73) Ibid., at pp. 100-101.
} 
as reference to peoples entitled to self-determination. ${ }^{74}$ The critical question for present purposes then is what meaning the formulators of the principle of permanent sovereignty over natural resources intended to ascribe to the term?

In many instances, scholars differ on this issue. Schrijver's view is that the term as used during deliberations preceding adoption of the resolutions on the principle, was used to refer to people who were still under colonial rule and were not yet able to exercise their right to economic self-determination. ${ }^{75}$ As they attained this right it no longer became relevant to refer to peoples. Duruigbo argues that although it can be concluded that reference to peoples was to people that were under colonial rule, there is good reason to believe that this right remained vested in the entire population of a country even after colonial rule had ended. ${ }^{76}$ This view, he argues, is supported by the fact that the African Charter, for example, makes use of the term peoples in vesting rights even though many countries in the region at the time it was adopted had already enjoyed independence for some time. ${ }^{77}$ Furthermore, that the term peoples must have meaning beyond foreign domination since it cannot be argued that the people lose their right after gaining independence. ${ }^{78}$

The present authors take the view that the term 'peoples' refers to the people of a country, in this instance the people of Zimbabwe relative to the natural resource - diamonds. As Murombo points out, 'the generic group of indigenous Zimbabweans is, however, by no means homogenous; neither does it represent people of equal political, social and economic stamina, nor persons with shared common interests. ${ }^{19}$ As a result, particular focus will be placed on the exercise of permanent sovereignty over natural resources by communities in which diamond deposits have been discovered and are being exploited.

\subsection{Legal Status of the Principle}

The trite sources of international law are treaties, custom and general principles of international law. The majority of the pronouncements on permanent sovereignty over natural resources, with the exception of its inclusion in the Human Rights Conventions, are however, contained not in universal conventions but in UN General Assembly resolutions. This has resulted in controversy over the legal status of the principle; that is to say, whether it is a binding principle of international law. Generally, resolutions of the UN General Assembly are not legally binding instruments although it has been argued that on occasion they

\footnotetext{
74) Gittleman, note 50 above, at p. 682.

75) Schrijver, note 42 above, at p. 9.

76) Duruigbo, note 2 above, at p. 53 .

77) Ibid.

78) Ibid.

79) T. Murombo, 'Law and the indigenisation of mineral resources in Zimbabwe: an equity for local communities?', 25 SA Public Law (2010), 568-589, at p. 577.
} 
have created law. ${ }^{80}$ While the UN General Assembly has no legislative powers, it is accepted that international organisations are a significant forum in which to search for sources of law and the acknowledgement of the contribution of the political organs to the development of international law has been even longer in coming. ${ }^{81}$ The argument is that, in practice, many of its resolutions have had effects in and on international law and as a result this broad construction of the UN General Assembly's powers is now established and accepted..$^{82}$ In other words, the UN General Assembly resolutions are a reliable source of state practice as a measure of the acceptance of any principle into international law. According to Onejeme, the UN General Assembly is 'today the most universal political organisation and is therefore the most important forum for measuring the degree of agreement among states in matters of international relations. ${ }^{\text {'83 }}$

Some of the resolutions that are considered as creating law include declaratory resolutions which authoritatively find out what the law is, for example, in situations where there may exist competing claims within an area of law but the rules are generally agreed upon. ${ }^{84}$ The drawing up of such resolutions can include debates, examination of issues in particular committees, invitation to governments to extend their opinions and guiding memoranda from the secretariat. These events, final votes and resolutions, according to Higgins, are part of the law developing process of the United Nations. ${ }^{85}$ While these actions do not create direct legal obligations for member states they can embody a consensus of opinion about what the law is so that they indirectly become evidence of the law. Resolutions that are adopted unanimously or nearly unanimously or by a true consensus carry considerable weight as interpretations of the UN Charter, statements of law or quasi-judicial determinations. ${ }^{86}$ In these instances, it is normally important that the affirmative votes should include those states whose support may be necessary for effective implementation as well as states from all economic and legal systems. ${ }^{87}$

In addition, it has been posited that UN General Assembly resolutions could create law in a manner that closely resembles the process involved in the creation of international custom. ${ }^{88}$ Norms set out in resolutions become legally

80) S.M. Schwebel, 'The effect of resolutions of the UN General Assembly on customary international law', 73 American Society of International Law and Procedure (1979), 301-333.

81) R. Higgins, 'The development of international law by the political organs of the United Nations', 59 American Society of International Law and Procedure (1965), 116-, at p. 117.

82) Schwebel, note 80 above, at pp. 303-304.

83) A.N. Onejeme, 'The law of natural resources development: agreements between developing countries and foreign investors', 5 Syracuse Journal of International Law and Commerce (1977), 1-52, at 9.

84) Higgins, note 81 above, at p. 116.

85) Ibid.

86) D.J. Harris, Cases and materials on international law 5 th edn. (Sweet \& Maxwell, London, 1998), 59.

87) Ibid.

88) M.E. Ellis, "The new international economic order and General Assembly resolutions: The debate over the legal effects of General Assembly resolutions revisited', ${ }_{5}$ California Western International Law Journal (1985), 647-704, at 689 . 
binding when the UN General Assembly formulates the norms, adopts the resolution overwhelmingly and with the intent for it to be legally binding. ${ }^{89}$ In determining whether the principle embodied in a resolution has created a new norm, one would properly focus on elements similar to opinio juris and State practice. ${ }^{90}$ Another factor relevant to the weight and effect of resolutions is their repetition and recitation in subsequent resolutions. ${ }^{91}$ The repetitive or cumulative factor is considered significant for a number of reasons. It demonstrates continuity; distinguishing those resolutions having stable support from those enjoying ephemeral support, strengthening their evidential and precedential value, and mobilises public opinion and legal thinking. ${ }^{92}$

The most important of the resolutions regarding permanent sovereignty over natural resources in the UN General Assembly was the 1962 Resolution. Since the discussions leading to its adoption, its legal effect and binding character had always been of particular interest. Gess, writing on the Resolution, notes that most of the member states held that the Resolution was intended to express existing law and the UN General Assembly only 'intended to set forth within the solemn vehicle of a declaration the basic principles and modalities of the exercise of permanent sovereignty. ${ }^{93}$ She concludes that the question of the international recognition and legal validity of the concept may be considered as one of secondary importance in so far as some of the operative paragraphs of the Resolution already have validity in international law and 'the concept only serves as a vehicle rather than as a determinant of the principles set forth in the Resolution. ${ }^{94}$ Schrijver is of a similar view and notes that 'elements of the 1962 Resolution could be placed in the category of declaratory resolutions in so far as it formulated a new opinio juris communis with respect to the principle. ${ }^{95} \mathrm{He}$ further proposes that the 'controversial aspects of the Resolution fall under the category of permissive resolutions which do not impose obligations. ${ }^{96}$ As Visser points out, in Texaco v Libyan Arab Republic it was held that 'Resolution 1803 is an expression of customary international law.'97

Outside the UN General Assembly resolutions, the main elements of permanent sovereignty over natural resources, particularly the sovereign right to make use of natural resources have found their way into conventions such as the 1966

\footnotetext{
89) Ibid.

90) Ibid., at pp. 689-69o.

91) South West Africa Case (1966) ICJ 292.

92) Ibid.

93) K.N. Gess, 'Permanent sovereignty over natural resources: an analytical review of the United Nations declaration and its genesis', 13 The International and Comparative Law Quarterly (1964), 398-449, at p. 409.

94) Ibid.

95) Schrijver, note 42 above, at p. 373.

96) Ibid.

97) Visser, note 31 above, at p. 86.
} 
Human Rights Conventions and the 1981 African Charter on Human and Peoples' Rights. Unlike the resolutions of the UN General Assembly, these treaties are legally binding on the parties to the treaties. In addition, the principle has also been recognised in a series of arbitral awards. ${ }^{98}$ Thus, from the above it is clear that the principle has achieved a 'firm status in international law and is now widely accepted and recognised as a principle of international law. ${ }^{\text {99 }}$ While Resolution 1803 was adopted by a majority of votes from all parties concerned, this was not the same for subsequent instruments. The CERDS, for example, was adopted with more abstentions and more capital exporting countries voting against it. ${ }^{100}$ This, however, was not because these countries objected to permanent sovereignty per se but rather the voting trends were a result of disagreements on the issue of compensation. ${ }^{101}$ These voting trends make it difficult to conclude that the principle, as enunciated in these other resolutions, has attained the status of customary international law, as a clear majority would have provided considerable evidence of an opinio juris.

With regard to Article 2(2) of CERDS, there is a proposition that it is an authoritative statement of public international law. ${ }^{102}$ The proposition is that the intention was to place the UN Charter on a firm legal footing; that the wording of the article implies a binding effect and that the Charter is more prescriptive than recommendatory. ${ }^{103}$ Visser dismisses the first two arguments on the basis that mere good intentions and much imagination are insufficient to make good law. He points out that further debates leading to the adoption of the Resolution show clearly that few of the members seriously believed they were creating law. ${ }^{104}$ In light of the discussion above, it is our view that, while the principle may not have attained the status of a fully fledged rule of customary international law, it is a widely accepted principle of international law. In addition, to the extent that it has been included in binding instruments, it is binding on the states that are parties to such instruments, and Zimbabwe is a party to one of such instruments - the African Charter on Human and Peoples' Rights.

\subsection{Content of the Principle}

Central to the principle of permanent sovereignty is the right of all peoples and states to freely dispose of their natural resources within the limits of their national

\footnotetext{
98) Texaco v Libyan Arab Republic 1978 (17) ILM para 59.

99) Schrijver, note 42 above, at p. 377.

100) Visser, note 31 above, at p. 83 .

101) Schrijver, note 42 above, at p. 377 .

102) F.V. Garcia Amador, "The proposed new international economic order: the new approach to the law covering nationalisation and compensation', cited in Visser, 'The principle of permanent sovereignty over natural resources and the nationalisation of foreign interests', CILSA (1988) 76-91, at p. 84.

103) Ibid.

104) Visser, note 31 above, at p. 85 .
} 
jurisdiction. This right is contained in every instrument on permanent sovereignty. In the exercise of this right, states are among other things entitled to regulate the admission of foreign investors, the methods of exploitation, conduct of the entities engaged in the exploitation and the distribution of profits. ${ }^{105}$ There has been considerable debate on the meaning and implications of the adjectives of 'permanent' and 'inalienable' that qualify the word 'sovereignty', as well as the meaning of 'sovereignty' on a state's right to freely dispose of its natural resources. ${ }^{106}$ With respect to the permanent nature of the right, among the views that have been put forward is that the right can always be regained, if necessary. ${ }^{107}$ Schrijver's view is that the right to dispose freely its natural resources will always vest with the state and it is the state's prerogative to assert this right at any given time; yet at the same time this right does not entitle it to revoke at its whim any limitations it may have legitimately placed on the exercise of its rights. ${ }^{108}$ He succinctly summarises the above view by stating that it is widely accepted that the principle precludes a state from derogating from the essence of the exercise of its sovereign rights over natural resources. ${ }^{109}$ Regarding the meaning of sovereignty in relation to the principle of permanent sovereignty over natural resources, the term can be generally stated as legal, governmental control and management authority over natural resources.' ${ }^{110}$

The principle of permanent sovereignty gives states the right to regulate and control the activities of foreign investors through domestic legislation and policies. In general, the issues regulated encompass the admission, general standard of treatment, expropriation and regulation of compensation and dispute settlement. ${ }^{111}$ Resolutions 1803 (XVII), 2158 (XXI), and 3281 (XXIX) are the most relevant as far as regulation of foreign investment is concerned. Under Article 3 of Resolution 1803 , the use of natural resources, as well as the import of foreign capital, should be in conformity with the rules and conditions which the peoples consider necessary, but once the state authorises the admission of foreign investment then that investment will be governed by the terms of authorisation, national legislation, and international law. Resolution 2158 on the other hand only makes reference to national laws and regulation with regard to exploitation of natural resources without making any reference to international law.

The most controversial right and one which resulted in considerable dissent in the discussions leading to the adoption of resolutions on permanent sovereignty over natural resources was the right to expropriate and nationalise foreign

\footnotetext{
105) Hofbauer, note 51 above, at p. 14.

106) Schrijver, note 42 above, at p. 262.

107) Ibid., at 263.

108) Ibid.

109) Ibid., at p. 264.

110) Daes, note 71 above, at p. 7.

111) Schrijver, note 42 above, at p. 264.
} 
investments. Paragraph 4 of Resolution 1803 dealing with the subject attempted to strike a balance between the interest of capital exporting countries and capital importing countries. ${ }^{112}$ It requires that nationalisation or expropriation would be permissible where undertaken 'for reasons of public utility, security or national interest.'113 In case of expropriation, the resolution requires that the owner of the expropriated property be paid compensation in accordance with the rules of the State taking the measure and in accordance with international law. ${ }^{114}$ Subsequent resolutions such as Resolution 3281 (CERDS), however, dropped the reference that compensation should be in accordance with international law; such omission resulted in the capital exporting countries voting against the Resolution. ${ }^{115}$ In addition, the use of the word 'appropriate' compensation also resulted in substantial debate. Resolution 1803 had distinguished between compensation for property acquired before the gaining of independence by colonised countries and measures taken after achieving self-determination. As a result, a paragraph was inserted to the effect that whatever was said in the resolution in relation to compensation would not apply to the taking of colonial property. ${ }^{116}$

As has already been alluded to, permanent sovereignty over natural resources emerged as a basic constituent of the right to self determination as well as an essential and inherent element of sovereignty. As a result, an element of sovereignty cannot give more rights and liberties than the concept of sovereignty itself. ${ }^{117}$ Permanent sovereignty over natural resources is therefore subject to the same limitations as the above-mentioned principles of self-determination. Sovereignty not only gives rights but also includes responsibilities. Similarly, permanent sovereignty over natural resources not only gives rights but also entails duties.

Most of the resolutions on the right of permanent sovereignty over natural resources state that the use of natural resources must be undertaken for the well-being of the people. The UN General Assembly clearly linked the exercise of sovereignty over natural resources with the requirement to promote national development and the well-being of the inhabitants. While international law literature has not meaningfully addressed the question of the exercise of permanent sovereignty over natural resources for the well-being of people, Schrijver notes that the duty 'reflects the spirit of the linkage between self-determination, realisation of socio-economic rights, and the subsequent linkage between the decolonisation process and the pursuit of development. 118 What this clearly illustrates is that the exercise of permanent sovereignty over natural resources was envisaged

\footnotetext{
112) Schrijver, note 42 above, at p. 260.

113) See paragraph 4 of the United Nations General Assembly Resolution 1803 (XVII).

114) Ibid.

115) Schrijver, note 42 above, at p. 106.

116) Preamble of Resolution 1803 (XVII).

117) Schrijver, note 42 above, at p. 263.

118) Ibid., at p. 295.
} 
for the attainment of a specific objective - that of well-being of people. This means that if diamonds, as a natural resource that Zimbabwe as a country and as a people have permanent sovereignty over are properly harnessed, they could lead to a better life for the people of Zimbabwe.

\subsection{Meaning of Development}

As it is not possible here to examine the meaning of development in detail, a cursory outline is provided. According to MacPherson, 'development is a complex and elusive concept often left undefined.'119 'The term is used freely, often indiscriminately, in a variety of contexts. ${ }^{120}$ 'Very often the meaning of development is assumed and not thought out. ${ }^{121}$ Despite the philosophical and perhaps epistemological differences about development, it could be argued that development is people-oriented and can only be measured with reference to its impact on people. In fact, there could be no other index with which to measure development, other than by reference to its impact on the well-being of people.

According to the seminal Report of the Independent Commission on International Development Issues (Brandt Report), development broadly refers to 'desirable social and economic progress' - although what is desirable for one person may not be desirable for another. ${ }^{122}$ The Report emphasises the importance of economic growth and industrialisation in the development process; 'for without growth and social change one cannot speak of development.'123 However, Walter Rodney, a renowned scholar, emphasised the importance of people in the development process. He argues that at the individual level development implies 'increased skill and capacity, greater freedom, creativity, self-discipline, responsibility and material well-being. ${ }^{124} \mathrm{He}$ acknowledges that some of these are moral categories, which are difficult to evaluate as they depend on one's age, class and code of what is right or wrong. ${ }^{125}$ But for Rodney, 'what is indisputable is that the achievement of any of those aspects of personal development is very much tied in with the state of the society as a whole.'126

Similarly, one of Africa's most respected figures, Julius Nyerere, opined that the purpose of development is the people. ${ }^{127} \mathrm{He}$ argued that things such

\footnotetext{
119) S. MacPherson, Social policy in the third world: the social dilemas of underdevelopment (Wheatsheaf Books, Brighton, 1982), at p. 18.

120) Ibid., at p. 19.

121) Ibid.

122) W. Brandt, Report of the Independent Commission on International Development Issues, NorthSouth: a programme for survival (Pan Books, London, 1980) 48.

123) Ibid.

124) W. Rodney, How Europe underdeveloped Africa (Bogle-L'Overture, London, 1972), at p. 9.

125) Ibid.

126) Ibid.

127) J.K. Nyerere, Freedom and development. Uhuru na maendeleo: a selection for writings and speeches 1968-1973 (Oxford University Press, Oxford, 1973), at p. 59.
} 
as 'roads, buildings and increased crop output are not development but tools of development.' ${ }^{128}$ These things can only be development if they are used to 'develop the minds and understanding of people or for other things that improve the health and comfort of the people.'129 This means that development 'must be judged by the criterion of whether it serves the people.' ${ }^{\prime 30}$ The various attempts at defining development show clear fundamental differences. The Brandt definition places primary emphasis on economic changes while Rodney and Nyerere focus on people. In order to contextualise the meaning of development and the debate surrounding its meaning, it is perhaps important to trace the history of the debate, albeit briefly.

According to Gordon and Sylvester, development in Least-Developed Countries (LDCs) has undergone a different form of metamorphosis since the 1950s - the period when it was assessed solely on the basis of economic growth. ${ }^{131}$ Even until recently, too often and unthinkably development has been defined as 'economic development, that is, economic or growth in resources.' ${ }^{132}$ While it is true that many items in the programme of changing life for the better require resources, such resources are mere means to defined goals and not ends in themselves. ${ }^{133}$ This became apparent because not many economic growth plans gave rise to any success that is measurable; hence it was quite clear that whatever gains that materialized would not translate to automatic benefit for citizens most in need. ${ }^{134}$ In the following years, other aspects were added to the definition of development and it became more wide ranging.

During the 1950s and 1960s economic growth as a tenet of the Modernisation Theory was seen as the panacea to dealing with development problems. ${ }^{135} \mathrm{How}-$ ever, economic growth did not necessarily lead to development as envisaged, leading to "widespread disillusionment" of developing world governments and scholars on the link promoted by the theory. ${ }^{136}$ The problem with economic growth under the Modernisation Theory was that it was top-down and therefore created economic enclaves and dependency. ${ }^{137}$ In other words, due to the focus

\footnotetext{
128) Ibid.

129) Ibid.

130) Ibid., at 60.

131) R.E. Gordon and J.H. Sylvester, 'Deconstructing development', 22 Wisconsin International Law Journal (2004), 1-79, at p. 29.

132) A. Allot, 'Development for what - false gods and holy writ', 3 Third World Legal Studies (1984), 1-10.

133) Ibid.

134) Gordon and Sylvester, note 131 above, at p. $3^{2}$.

135) D. Hulme and M. Turner, Sociology and development: theories, policies and practices (Harvester Wheatsheaf, New York, Ny, 1990), at p. 34; C. Leys, The rise and fall of development theory (Currey, London, 1996), at p. 10.

136) Hulme and Turner, note 135 above, at pp. 41-42; S. Treurnicht, 'From modernisation to sustainable development', in H. Swanepoel and F. de Beer (eds), Introduction to development studies (International Thomson, Johannesburg, 1997), pp. 17-41, at p. 21.

137) Hulme and Turner, note 135 above, at p. 39; Leys, note 135 above, at p. 12.
} 
on economic growth, 'peripheral countries specialised in primary products while importing consumer goods that were fruits of technical progress in developed countries.' 138

Among the scholars disillusioned by idea of economic growth as the solution to development woes is Sen, who argues that economic 'growth is not the same thing as development' but is certainly one aspect of the 'process of development.'139 Sen further argues that the traditional conceptualisation of development was limited in that it did not recognise that 'economic growth was no more than a means to some other objectives. ${ }^{140}$ Instead of focusing on economic growth, that is, 'national product, aggregate and total supply of particular goods', development should be concerned with 'entitlements of people and capabilities these entitlements generate. ${ }^{141}$ For Sen, 'development involves reducing deprivation or broadening choice. ${ }^{142}$ According to Nayaran et al., 'deprivation represents a multidimensional view of poverty that includes hunger, illiteracy, illness and poor health, powerlessness, voicelessness, insecurity, humiliation, and a lack of access to basic infrastructure. ${ }^{143}$ It is in this regard that Sen insists that 'development has to be concerned with what people can or cannot do; for example, whether they can live long, escape avoidable morbidity, be well nourished, be able to read and write and communicate, take part in literary and scientific pursuits, and so forth.' 144

On 4 December 1986, the UN General Assembly adopted a Declaration recognising the right to development as an inalienable human right. ${ }^{145}$ The preamble of this Declaration echoes the same views on development as those of Sen and recognises that 'development is a comprehensive economic, social, cultural and political process which aims at the constant improvement of the well-being of the entire population and of the individual on the basis of their active, free and meaningful participation in the development and in the fair distribution of benefits resulting therefrom. ${ }^{146}$ The Declaration, in addition to recognising the complexity of development, entrenches a rights-based approach to development. ${ }^{147}$

138) E.W. Nafziger, 'From Seers to Sen: the meaning of economic development', paper presented at the UN University/World Institute for Development Economics Research (WIDER) Jubilee Conference, 17-18 June (2005), 5 .

139) A. Sen, 'Development: which way now?', 93 The Economic Journal (1983), 745-762, at p. 748.

140) Ibid., at 753 .

141) Ibid., at 754 .

142) Nafziger, note 138 above, at p. 1.

143) D. Narayan, R. Patel, K. Schafft, A. Rademacher and S. Koch-Schulte, Voices of the poor: can anyone hear us? (Oxford University Press, New York, NY, 2000), at pp. 4-5.

144) Sen, note 139 above, at p. 754.

145) United Nations Declaration on the Right to Development (Res/41/128).

146) Preamble of the Declaration on the Right to Development.

147) K. de Feyter, 'Contracting for human development: international law and development revisited', 10 Asia Pacific Law Review (2002), 49-74, at 57. 
Bradlow distinguishes between the traditional view and the modern view of development. ${ }^{148}$ The traditional view sees 'development primarily as an economic process that could be achieved through projects such as constructing a dam, a road, a school, a factory, a mine or a telecommunications system.' ${ }^{\prime 49}$ This view recognises that development has 'social, environmental, and political implications but argues that these can be dealt with separately from the economic aspects. ${ }^{\prime 150}$ On the other hand, proponents of the modern view argue that development 'cannot be separated from its social, political, environmental and cultural aspects.' ${ }^{\text {'151 }}$ From this perspective, 'development projects and policies should be treated as episodes of social, economic and environmental transformation that are part of an on-going process of change. ${ }^{\prime 52}$ Depending on which view one subscribes to, these two perspectives differ in terms of their 'understanding of the substantive content of development and the importance they attach to the principle of sovereignty and how it is applicable to the development process.' ${ }^{153}$

Despite the debate around the meaning of development, there is consensus that it encompasses 'the need to accelerate growth and reduce hunger, poverty, illiteracy, preventable diseases, LDC debt burdens, gender inequalities and unsustainable environmental damage.' ${ }^{\prime 54}$ For MacPherson, while the constituent of improvement may be debatable, development can be equated to improvement. ${ }^{155}$ Thus, the debate on the concept of development must be contextualized in the history, culture and, more importantly, the needs of the society concerned. ${ }^{156}$ As alluded to by Peet and Hartwick, development must have to do with how the resources in the society are used to improve the life of the generality of the society particularly the poor ${ }^{157}$ and must pay attention to 'human emancipation and human welfare.'158 This would mean improvement in complex areas that are linked to each other such as the 'natural, economic, social, cultural, and political conditions' of the society. ${ }^{159}$ All in all, development is a complex, contradictory phenomenon, which, as concluded by Peet and Hartwick, is 'one reflective of the

\footnotetext{
148) D.D. Bradlow, 'Differing conceptions of development and the content of international development law', 21 South African Journal on Human Rights (2005), 47-85, at 52.

149) Ibid., at 53 .

150) Ibid.

151) Ibid., at 67.

152) Ibid.

153) Ibid., at 47.

154) Nafziger, note 138 above, at p. 16.

155) MacPherson, note 119 above, at p. 19.

156) Ibid., at 20.

157) R. Peet and E. Hartwick, Theories of development: contentions, arguments, alternatives (Guilford Press, Abingdon, 2009) 1.

158) Ibid.

159) Ibid.
} 
best of human aspirations and yet subject to the most intense manipulation and liable to be used for purposes that reverse its original ideal intent.'160

As already shown, defining the term development is a complex task complicated by debates among experts. The meaning of the term varies between different schools of thought and political traditions. However, it can be defined as processes, action and change of economic, political and social conditions of societies. Inherent in the meaning of development is the notion of progress, which implies positive movement, of course bearing in mind that what is positive is normative. In this article, we do not attempt to provide a precise definition of development, but with all its deformities, the above definition seems encompassing and will thus be adopted as the meaning of development. From the definition, the interrelationship of economic, political and social conditions is seen where a country can use proceeds from its economic resources to provide social services such as education and healthcare to its citizens. Whatever definition one adopts, ultimately development has to be measured in relation to people; its positive impact on life and people, otherwise it would remain an abstract concept of no relevance outside academic discourse.

To sum up, the principle of permanent sovereignty over natural resources was first introduced by Chile in the UNCHR in 1952. The principle would subsequently develop through numerous resolutions and declarations. While other aspects of permanent sovereignty can only be exercised through the state, we argue that the right to permanent sovereignty over natural resources accrues primarily to peoples. Although the principle may not have attained the status of a fully-fledged rule of customary international law, it is a widely accepted principle of international law. Central to the Principle is the right of all peoples and states to freely dispose of their natural resources within the limits of their national jurisdiction. What is clear is that the exercise of permanent sovereignty over natural resources was envisaged for the attainment of a specific objective, that of development or well-being of people. The principle therefore is the premise on which this article posits that Zimbabwe's diamonds should be used for the well-being of its people who constitute society.

\section{Zimbabwean Diamonds as a Natural Resource}

\subsection{Background}

Zimbabwe is a country endowed with vast mineral wealth, the most important probably being the recently discovered diamonds. Much of Zimbabwe lies on the

160) Ibid., at p. 2. 
Archaean Craton which is conducive to Kimberlitic deposits. ${ }^{161}$ Yet in spite of its mineral wealth, the United Nations estimates that 1.2 million Zimbabweans live with HIV, millions lack access to clean water and sanitation and approximately one third of all children under the age of seven are malnourished and suffer from malnutrition. ${ }^{162}$

Before 2004, diamond production was limited to accidental finds in alluvial diggings, with the exception of the River Ranch Kimberlite Mine. ${ }^{163}$ The mine opened in 1995 but ceased operations in 1998 because of low diamond prices. ${ }^{164}$ Bubye Minerals was appointed by an auditing firm to carry out operations. The Mine became embroiled in a battle for its ownership and in 2007 it was reported as having been prevented from exporting diamonds as a result of a pending court case. ${ }^{165}$ Currently the mine remains in the hands of Rani International, an estate of the late Solomon Mujuru, a former general of the Zimbabwean Army. ${ }^{166}$ The mine continues to export diamonds though the value of its exports is unknown. ${ }^{167}$ In 1997, Rio Tinto Zimbabwe, a subsidiary of Rio Tinto PLC discovered the Murowa Kimberlite cluster in the South Western part of Zimbabwe. ${ }^{168}$ Murowa production is estimated to average about US $\$ 65$ per carat over the life of the mine. ${ }^{169}$

The year 2006 was marked by the discovery of diamonds in the Chiadzwa and Chirasike areas of Marange district in Manicaland province. ${ }^{170}$ This discovery brought the number of diamond mining sites in Zimbabwe to three. ${ }^{171}$ Following this discovery a frenzied diamond rush ensued, fuelled by a declaration by ruling party officials that the diamond fields were free and open to anyone wishing to look for diamonds. ${ }^{172}$ Subsequent government attempts to control illegal diamond miners through the use of military personnel generated allegations of grave abuses of human rights, corruption and smuggling of diamonds. ${ }^{173}$

161) Partnership Africa Canada, 'Zimbabwe, diamonds and the wrong side of history' (Occasional Paper 18, 2009), available online at http://www.pacweb.org/documents/diamonnds_KP/18_Zimbabwe Diamonds_ March o9-Eng.pdf (last accessed 15 July 2011).

162) Human Rights Watch, 'Deliberate chaos: ongoing human rights abuses in the Marange diamond fields of Zimbabwe', available online at http://www.hrw.org/en/reports/2010/o6/21/deliberate-chaos (last accessed 15 July 2011).

163) Partnership Africa Canada, note 161 above, at p. 11.

164) Ibid.

165) Ibid.

166) Ibid., at 12 .

167) Ibid.

168) Murowa Diamonds 'Sustainability report 2007. Murowa Diamonds. more than diamonds', available online at http://www.riotinto.com/documents/ReportsPublications/FINAL___Murowa_Diamonds_ Sustainability_Report_2007.pdf (last accessed 15July 2011).

169) Partnership Africa Canada, note 161 above, at p. 6.

170) Human Rights Watch, note 162 above, at p. 10.

171) Human Rights Watch, 'Diamonds in the rough: human rights abuses in the Marange diamond fields of Zimbabwe', available online at http://www.unhcr.org/refworld/docid/4a447ffi2.html (last accessed ${ }_{15}$ July 2011).

172) Ibid., at p. 14.

173) Ibid. 
Originally, mining of diamonds in the Marange diamond fields was carried out by the government-owned Zimbabwe Mining Development Corporation (ZMDC). It became clear, however, that the company lacked capacity to properly exploit the fields. Currently, the state, through Marange Resources Private Limited, exploits the fields through its joint ventures with Grandwell Holdings and Core Mining and Minerals Limited. ${ }^{174}$ A number of the shareholders of these two companies are people who are members of the army or who have at one point or another served within the armed forces. ${ }^{175}$ There is also information to show that other companies have been awarded contracts to mine the diamonds, however it is difficult to ascertain who these companies belong to as the whole process has been shrouded in secrecy and lacks transparency. ${ }^{176}$ According to a Human Rights Watch Report, the public tender processes that are required by Zimbabwean law have been ignored in awarding the contracts. ${ }^{177}$

In order to make way for the mining operations, the people of Marange who occupied the land on which the diamond fields are located have been forcibly relocated. ${ }^{178}$ These relocations have taken place without proper consultation on the time frame for relocation and on the levels of compensation. ${ }^{179}$ In addition, the farm to which the relocated families have been moved is far from the diamond fields and lacks proper social amenities.

The actual size and potential of these diamond fields is unknown. ${ }^{180}$ The Reserve Bank Governor estimated the possible revenue from the diamonds to be US $\$ 1.2$ billion a month if properly mined. ${ }^{181}$ African Consolidated Resources, a company which owned title to the Marange diamond fields before the government took over claims that if the area is mined at a responsible rate Marange output could sustain three million carats a month for fourteen years. ${ }^{182}$ These statistics indicate that diamond revenue in Zimbabwe has a potential of contributing to economic growth which if properly harnessed could lead to poverty reduction and development. On the other hand, they show that there has been gross mismanagement of the Marange diamonds and as a result only a few individuals are benefiting from their exploitation. ${ }^{183}$ As Mtisi et al. point out, the situation in Marange paints a bleak picture, 'it is a story of poverty, corruption, and mismanagement of mineral resources starting from the underground mining

\footnotetext{
174) S. Mtisi, M. Dhliwayo and G. Makore, Extractive industries policy and legal handbook (Zimbabwe Environmental Law Association, Harare, 2011), at p. 39.

175) Human Rights Watch, note 161 above, at p. 6.

176) Mtisi, Dhliwayo and Makore, note 174 above, at p. 35.

177) Human Rights Watch, note 161 above, at p. 6.

178) Mtisi, Dhliwayo and Makore, note 174 above, at p. 35.

179) Ibid., at p. 40.

180) Partnership Africa Canada note 1 above, at p. 14.

181) Ibid., at 6.

182) Ibid., at 14.

183) Mtisi, Dhliwayo and Makore note 174 above, at p. 7.
} 
pits to the air conditioned offices of government officials and company executives in Harare. ${ }^{184}$ It is also a story of environmental degradation and pollution of water systems, loss of livelihoods, forced evictions and relocation, dilapidated infrastructure and poor road networks in the areas where mining companies are operating. ${ }^{185}$ Natural resources are being exploited for the benefit of a few politically and economically connected individuals, a few state institutions and foreign nations at the expense of all Zimbabweans. ${ }^{186}$

\subsection{Regulation of Mining in Zimbabwe}

For mining to result in significant benefits, it is asserted that the presence of a number of factors which include among them, an appropriate legal and policy framework, adequate level of political stability and well defined property rights, must exist. ${ }^{187}$ For purposes of this article it is therefore essential to enquire into whether, and the extent to which Zimbabwe's mining legal framework relating to diamonds is facilitative of people-oriented development and thus leads to ending the problem highlighted above. As will be recalled from the earlier discussion on development, some of the core aspects of development include the participation of people in charting their own course of development, and preservation of the environment. This enquiry will therefore seek to highlight how and if at all Zimbabwe's mining legislation facilitates the realisation of these aspects. Particular focus will be given to how benefits from diamond mining are utilised and shared, participation of communities and sustainable extraction of diamonds.

Murombo points out that 'Zimbabwe has lagged behind in the establishment of an enabling legal and policy framework for sustainable and equitable mineral resources development.'188 This is certainly so because the principal regulatory instrument governing mining in Zimbabwe is the Mines and Minerals Act (Chapter 21:05) of 1961. This piece of legislation was enacted during the colonial era and has been retained with only minor amendments. Its main focus was to facilitate maximum extraction of natural resources by the colonial government and the mining companies that often bankrolled that government and, in spite of the various amendments, the focus has remained the same. ${ }^{189}$ The country does not have any independent mining policy documents and it is in this Act that policy relating to mining is also found.

The Act vests dominium in all mineral resources and the right of searching, mining and disposing of all minerals in the President, notwithstanding the dominium

\footnotetext{
184) Ibid.

185) Ibid.

186) Ibid.

187) J.O. Mugabe and G.W. Tumushabe, in Murombo 'Law and the indigenisation of mineral resources in Zimbabwe: an equity for local communities?', 25 SA Public Law (2010), 568-589, at p. 571.

188) Murombo, note 79 above, at p. 572.

189) Ibid., at p. $5^{80}$.
} 
which any person may possess in and to the soil on or under which such minerals are found. ${ }^{190}$ Under the provisions of the Act, royalties from mining activities are recovered by the central government. ${ }^{191}$ According to Section 245 of the Act, local authorities can only benefit directly from royalties paid by mining entities where the Minister of Mines has by statutory instrument authorised this. The inclusion of peoples in benefiting from diamond mining revenues is further weakened by the absence of legal rights to substantiate the claims to benefits. ${ }^{192}$ As Murombo asserts, the only way in which local communities benefit is through development initiated by the central government and 'other incidental infrastructure put in place by mining companies. ${ }^{\prime} 93$

Further, the Mines and Minerals Act does not have provisions for the participation of local communities, even those that are most affected by mining activities. Management of the mining sector is therefore the prerogative of government without any input from the community. This problem is made worse by land tenure regulations. In terms of the Communal Lands Act (Chapter 20:04), land is owned by the state and the people only have usufructuary rights for agriculture, accommodation and grazing. ${ }^{194}$ The effect of this is that the people are in no position to exercise the content of permanent sovereignty over natural resources and effectively limits any say that peoples may have on how resources will be utilised, and how they would want to benefit from these resources. People, particularly those most affected by mining, are as a result in no position to make any claims on how they would want to benefit or share in diamond revenues as they do not own the land. They cannot challenge forced evictions from mineral bearing land which they may have occupied or challenged compensation schemes - a situation that is currently faced by the people of Marange. ${ }^{195}$

While the Mines and Minerals Act does not address environmental concerns caused by mining activities, the Environmental Management Act (Chapter 20:27) in some way alleviates the shortfalls of the mining regulations. It is an Act that aims to provide 'for the sustainable management of natural resources and protection of the environment.' ${ }^{196}$ The importance of this Act lies in the fact that it prevails over any law that is in conflict or inconsistent with it. In addition, Section 4 of the Act recognises the right of every person 'to participate in the implementation of the promulgation of legislative and other measures that secure ecologically sustainable management and use of natural resources while promoting justifiable economic and social development.' Further, Section 97 of the same Act requires

\footnotetext{
190) Section 2 of the Mines and Minerals Act 38 of 1961.

191) Section 244 of the Mines and Minerals Act 38 of 1961.

192) Murombo, note 79 above, at p. 579.

193) Ibid., at p. 581.

194) Mtisi, Dhliwayo and Makore, note 174 above, at p. 22.

195) Ibid.

196) Environmental Management Act 13 of 2002.
} 
an Environmental Impact Assessment (EIA) to be carried out before any mining operations are carried out and thus counters the lack of such provisions in the Mines and Minerals Act. While the provisions of the Environmental Management Act in some way counter the absence of environmental concern in the Mines and Minerals Act, in reality, policy makers always give precedence to the mining laws even if sometimes it is at the expense of the environment. ${ }^{197}$

In 2007, a bill was drafted to amend the Mines and Minerals Act and since then the bill has been withdrawn and reintroduced. As of November 2011, the bill was yet to go before parliament. The bill offers some improvements to the shortcomings in the Mines and Minerals Act. It introduces, among other things, important environmental protection measures such as the requirement of (EIAs), and the provisions on the creation of an Environmental Rehabilitation Fund (ERF). Yet, in spite of the above-mentioned improvements, the bill however falls short in many ways. Among the short comings is the fact that the bill makes limited reference to benefit-sharing and local community participation. ${ }^{198}$ Alternatively, the Minister of Finance has proposed the introduction of a Diamond Act, which will, among other things, deal with ownership of diamonds, criteria for the selection of investors, environmental concerns, compensation of displaced people, monitoring of diamond revenues and the creation of a Diamond Generation Fund (DGF). ${ }^{199}$

Another important regulatory instrument that has far reaching implications for the mining sector is the Indigenisation and Economic Empowerment Act (Chapter 14:33) that was passed together with Indigenisation and Economic Empowerment (General) Amendment Regulations (SI 116 of 2010). The Act and its regulations require that all foreign owned companies whose capital value exceeds a certain threshold should relinquish at least $51 \%$ of their shares to indigenous Zimbabweans. The provision of the regulations that is of importance to people's development is that there is an option for businesses to give some shares to community share ownership schemes or Trusts. ${ }^{200}$ Under this provision, the people therefore have an opportunity to participate and share in diamond revenues and map their development.

Although the history of diamonds in Zimbabwe is very short, the estimated diamond revenue in Zimbabwe has a potential of contributing to the well-being of its peoples. There is, however, lack of transparency on how diamond revenues are managed and as a result very few people are benefiting. This situation is compounded by the statutory instruments governing mining which are not development-oriented, as canvassed in this article.

\footnotetext{
197) Murombo, note 79 above, at p. 583 .

198) C. Anderson, 'Creating a legislative framework to govern mining in Zimbabwe', available online at www.revenuewatch.org (last accessed 7 November 2011).

199) Mtisi, Dhliwayo and Makore, note 174 above, at p. 58.

200) Section $14 \mathrm{~b}$ of the Indigenisation and Economic Empowerment Act 14 of 2007.
} 
Perhaps, the recently adopted new Zimbabwean constitution will have some impact, for purposes of development, on the regulation of diamonds and other minerals in the country in the future. On 21 May 2013 President Mugabe signed the new constitution (Constitution of Zimbabwe Amendment (No. 20) Act, 2013) into law following an earlier national referendum were voters massively approved the constitution. One hopes that the attention given to the development of people in the constitution would trigger a new regulatory sense. Under chapter two of the said constitution that deals with 'Objectives to guide State and all institutions and agencies of Government', Section 18(2) of the constitution obligates the state, the government, its institutions and agencies 'at every level' to 'take practical measures to ensure that all communities have equitable access to resources to promote their development.' The preamble to Chapter 14 of the constitution enshrines the 'devolution of power and responsibilities to lower tiers of government' so as to ensure 'equitable allocation of national resources and the participation of local communities in the determination of development priorities within their areas.' Not only does the Constitution seek to ensure that people benefit from national resources, it also provides for equitable sharing of 'the burdens and benefits of the use of resources between present and future generations' in Section 298(1)(c).

\section{The Principle of PSNR as a Vehicle for Development Using Zimbabwe's Diamonds}

Any rights that peoples may claim must have a legal basis and be defensible. ${ }^{201}$ More and more, international law is giving scrutiny to issues that previously would have been considered to be within a state's jurisdiction. As Bradlow points out, international law is now also, among other things, 'concerned with the legal rules and procedures that will lead to development policies and projects that are economically, environmentally, socially and legally sustainable as it is with rights and responsibilities arising from state relations. ${ }^{202}$ It is therefore not an anomaly that an international law principle could be used to address challenges to development. International law therefore has a role to play in clarifying governments' responsibilities and peoples' rights as this becomes important where there is a lack of political will by governments to act in the interests of people. ${ }^{203}$ Permanent sovereignty over natural resources, as formulated in 1962, requires that the right be exercised for the development and well-being of peoples. ${ }^{204}$ Thus, this section of the article focuses on how the principle of permanent sovereignty over natural

\footnotetext{
201) Murombo, note 79 above, at p. 573 .

202) Bradlow, note 148 above, at p. 74 .

203) Schrijver, note 42 above, at p. 37.

204) GA Res 1803 (XVII), UN. Doc A/5217 (Dec 14, 1962).
} 
resources can act as a legal means of ensuring development for the benefit of the people by addressing the deficiencies in the regulation of mining in Zimbabwe.

The principle of permanent sovereignty over natural resources is an instrument on which such reform can be based. The importance of the use of PSNR as a tool for development lies in the fact that the principle is not likely to wither away in the near future. ${ }^{205}$ In addition, as Schrijver points out, the principle 'has responded dynamically to changed circumstances and insights by integrating developmental and environmental concerns and by elaborating policy measures that are needed at the national and international level to fully implement the principle of permanent sovereignty. ${ }^{206}$ It is clear from the above statement that not only is PSNR a tool for economic development, but it has the potential to inform the regulation of the whole life cycle of diamond mining in a manner that brings about the realisation of all, if not most of the elements of development outlined earlier. Further, the principle no longer serves as a source of freedom of states to manage natural resources but also as a source of corresponding responsibilities requiring careful management and imposing accountability at international levels. ${ }^{207}$ The principle can therefore serve both as an instrument for informing the regulation of mining and also as a means of holding government officials accountable for their actions with regards to diamond revenues and thus ensure that the funds are properly harnessed for purposes of development.

As a right accruing to peoples, the principle must be read as giving people the basis on which to demand greater participation in the formulation of development policies and to make contributions on issues relating to exploitation of natural resources. This is of importance to people who reside in areas in which the natural resources are located as there is a great possibility that they will be adversely affected. According to Murombo, 'in the context of mining, local community participation in the mining industry can be argued to require substantive involvement or inclusion superimposed and going beyond the general guarantees of procedural participation.' ${ }^{208}$ This is because procedural participation does not guarantee an equitable distribution of benefits. The benefits to be derived from mining activities depend, among other things, on the leverage that communities have in negotiating with government and mining companies. Permanent sovereignty over natural resources as a right of peoples will ensure that peoples as owners of the right cannot be side-lined from being part of negotiations regarding exploitation of natural resources and also give communities the leverage that will ensure that their concerns are taken into account. Among other things, the people will therefore participate in deciding who will exploit their natural resources, how this will be carried out and what benefit they should get from these operations.

\footnotetext{
205) Schrijver, note 42 above, at p. 395.

206) Ibid., at 379 .

207) Ibid., at 393 .

208) Murombo, note 79 above, at p. 575 .
} 
There is therefore need to lobby for the recognition and inclusion of permanent sovereignty over natural resources as a right of peoples in Zimbabwe's legislation governing mining. This is presently absent as a normative value in Zimbabwe's natural resources legislation and regulation.

As Crawford points out, if the phrase 'right of peoples' is to have any independent meaning, it must confer rights on peoples against their own governments. ${ }^{209}$ In other words, the real content of the right lies in it being able to be enforced against the government of the state in question. ${ }^{210}$ The acknowledgement of the principle of permanent sovereignty over natural resources expressed in this manner in Zimbabwe's legislation would have several important implications which could enhance development of peoples. The principle is capable of operating as a guarantee of peoples' rights against their own governments, limiting the capacity of governments from acting contrary to the interests of the community. Further, Dufresne argues that 'what operates as a state prerogative to be exercised against other actors in the international society can be recast simultaneously as an empowering privilege against other groups within the state. 211 In addition, the acknowledgment that the resources of the country belong to the peoples of Zimbabwe paves the way to the idea that natural resources can be 'managed to further individual benefit and free choice without intermediate government ownership in the public name.'212 This would then make it possible to establish a Fund in which all diamond revenue can be deposited and used for the development of all people.

One cannot agree more with Duruigbo that, 'when resources belong to peoples it is not only limited to peoples today, but also includes peoples that are yet to be born. ${ }^{213}$ Permanent sovereignty over natural resources would therefore require the use of natural resources that is sustainable and ensure that exploitation activities that severely endanger the environment are open to censure. Further, people would be empowered to demand greater responsibility and compensation with regards to environmental damage and the rehabilitation of land that would have been adversely affected from those who would be involved in exploitation and the carrying out of proper EIAs. This is particularly of importance as often there is a lack of enforcement of environmental laws by authorities. Where such situations arise then affected communities can always rely on their sovereignty over natural resources to ensure that resource exploitation is carried out responsibly.

The above-mentioned proposals would, however, only succeed where there is political will on the part of those in authority to acknowledge the principle.

209) Crawford, note 62 at 143 .

210) Ibid., at 145 .

211) R. Dufresne, 'The opacity of oil: oil corporations, internal violence and international law', $36 \mathrm{NYU}$ Journal of International Law and Politics (2003), 331-394, at p. 357.

212) Duruigbo, note 2 above, at p. 68.

213) Ibid., at p. 61. 
Such a situation is difficult to envisage in Zimbabwe where allegations of corruption among authorities are rife. Even if the principle of permanent sovereignty over natural resources was to be incorporated into the country's legislation, this would not necessarily entail that those in power will abide by what it stands for. The problem is further compounded by the fact that presently Zimbabwe's legal framework lacks any enforceable community rights. This would therefore make it difficult for people to hold those who abuse diamond revenues accountable within the legal system. The principle of permanent sovereignty over natural resources as an international law principle then becomes of importance in ensuring the development of the people of Zimbabwe from diamonds.

Zimbabwe has ratified the ICESCR and the African Charter on Human and Peoples' Rights in which permanent sovereignty over natural resources is not only recognised but is a part of and is therefore bound by these instruments. The government is therefore under a duty to respect and fulfil the rights enunciated in these documents. The fact that Zimbabwe is a party to these instruments provides a platform for people to demand that their permanent sovereignty should be acknowledged by requiring that the government comply with its duties. In addition, not only is it possible that it can limit what governments can do, in the case of provisions such as Article 21 of the African Charter of Human and Peoples' Rights, it could make a state's natural resource policy justiciable before the African Commission on Human and Peoples' Rights. ${ }^{214}$ This would go a long way in ensuring that diamond revenue is accounted for and is used for development purposes.

The tendency of viewing permanent sovereignty over natural resources as a right accruing to states has overshadowed the fact that people should be the beneficiaries of any exercise of this right. ${ }^{215}$ This has resulted in a lack of development of people from natural resources as revenue from exploitation of such resources has found its way into the pockets of the elite. According to Reismann, viewing the right as vested in people opens up the possibility that spoliations, even by government officials, will be viewed as violations of internationally guaranteed rights of peoples to use their natural wealth for their well-being. ${ }^{216}$ Like any other grave violations of human rights, violations of permanent sovereignty over natural resources will limit if not exclude the defence by governments involved in spoliation that the matter is essentially within the jurisdiction of the state. ${ }^{217}$ This in turn will provide a basis for international condemnation and probably deter financial institutions in which the spoliated funds are deposited from accepting these funds. ${ }^{218}$

\footnotetext{
214) Crawford, note 62 above, at p. 143 .

215) Duruigbo, note 2 above, at p. 44.

216) W.M. Reisman, 'Harnessing international law to restrain and recapture indigenous spoliations', 83 The American Journal of International Law (1989), 56-59, at $5^{8 .}$

217) Ibid.

218) Ibid.
} 


\section{Conclusion}

This article has established that the international law principle of permanent sovereignty over natural resources emerged as a basic constituent of the right to selfdetermination, as well as an essential and inherent element of sovereignty. The principle recognises the right to determine the use of their natural resources so as to ensure the realisation of economic development and well-being of people. Although the principle may not have attained the status of a fully-fledged rule of customary international law, it is a widely accepted principle of international law. In addition, to the extent that it has been included in binding instruments the principle is binding on the states (including Zimbabwe) that are parties to such instruments.

Despite the debate around the meaning of development, there is consensus among scholars for the need to accelerate growth and reduce hunger, poverty, illiteracy, preventable diseases, LDC debt burdens, gender inequalities and unsustainable environmental damage. This means that development pays attention to human emancipation and human welfare. However, in order for development to be achieved people need to be active participants in the processes. Despite the fact that the term 'peoples' is used in this case to refer to the people of Zimbabwe, Zimbabweans are by no means homogeneous. As a result, the exercise of permanent sovereignty over natural resources is placed on communities in which diamonds deposits have been discovered and are being exploited.

As a right accruing to peoples, the principle must be read as giving people the basis on which to demand greater participation in the formulation of development policies and to make contributions on issues relating to exploitation of natural resources. However, legislation that governs mining in Zimbabwe such as the Mines and Minerals Act Chapter (21:05) of 1961 is not facilitative of the formulation of permanent sovereignty over natural resources as a right of peoples as it vests the custodial right over the country's mineral resources in the President. This creates an opportunity for abuse as it limits the extent to which people can exercise the content of the principle. It also effectively limits any say the people may have in how revenue from the sale of diamonds is utilised, and how they would want to benefit from it. There is therefore need for a legal framework that devolves responsibilities to local people and empowers them to take control of the management of natural resources.

It is quite clear that the principal regulatory instrument governing mining in Zimbabwe did not envisage development as an objective. Our view is that development will take place when there is accountability, transparency and when diamond revenues flow back into communities as recognition of the people's right to permanent sovereignty over natural resources. Legislative reform is therefore imperative to ensure that a main goal of Zimbabwe's mining regulation is the development of the people of Zimbabwe. With the recent constitutional reform 
and the in-process amendment to the Mines and Minerals Act, or alternatively the Diamond Bill, perhaps the hope is now hinged on how the promising provisions of the new Zimbabwean that we have highlighted are implemented. The new constitution provides an opportunity to take a people-centered development process into account within the premise that Zimbabwe's permanent sovereignty over its natural resources, such as diamonds. 